\title{
農業従事者，食品開発者，流通業者，一般消費者功みた 遺伝子組換え食品
}

上田 秀樹, 村上ゆき, 大野恵理香, 田中 沙知, 伊藤 有理, 北尾 悟

(大阪樟蔭女子大学)

\section{How do farmers, food developers, distributors, and consumers consider genetically modified food?}

\author{
Hideki Ueda, Yuki Murakami, Erika Ono, Sachi Tanaka, Yuri Ito, Satoshi Kitao
}

Osaka Shoin Women's University, 4-2-26 Hishiyanishi Higashiosaka-shi Osaka, 577-8550

干577-8550 大阪府東大阪市菱屋西 4-2-26

\begin{abstract}
The purpose of this study was to investigate how genetically modified (GM) food is considered by those who participate in food processing, namely, food farmers, food developers, distributors and consumers, from production to consumption.

The findings indicate that food developers were more interested in genetic recombination technology than other groups, whereas consumers were more interested in GM food. The number of people who think that application for genetic recombination technology to food production and other fields was not good for citizens was as follows in declining order: farmers $>$ consumers $>>$ distributors $>$ developers. Compared to other sources, newspapers were not a reliable source for information on GM food. In particular, food developers and distributors had more this tendency. Every organization including the Minister of Health, Labour and Welfare, the Minister of Agriculture, Forestry and Fisheries, and researchers of universities should be responsible for informing the nation of this technology.

In conclusion, it is important that all the parties concerned with genetic recombination technology continue to inform the public of this technology steadily to help the nation understand GM food.
\end{abstract}

\section{I．緒言}

世界の遺伝子組換え農作物の栽培面積は年々増え続け ており，2005年には9,000万へクタールにまで達し，こ の数值は日本の国土の約 2.4 倍に相当する。作物別では ダイズが約 $60 \%$ を占め, トウモロコシ, 綿, ナタネと併 せて作付け農作物のほぼ100\%を占めている。また，国 別ではアメリカが約55\%であり，2005年における組換え ダイズの栽培面積はダイズの総栽培面積の約 $87 \%$ となっ ている。我が国のアメリカからのダイズの輸入量は年間 500万トンを超えており1)，アメリカの組換え農作物の 作付け状況は非常に気になるところである。現在，商業 栽培実績のある農作物は，そのほとんどが農業従事者に 利便をもたらす生産性の向上に関わるものである。日本 では色変わりカーネーションの事例があるが食用ではな
い。最近, 生産性向上以外として, 不良環境でも生育で きる環境耐性形質をもつ農作物, 栄養素を付与した農作 物や血圧抑制・花粉症緩和などの機能を付与した農作物 など，組成や機能を改良し品質向上や消費者に利便をも たらすことを目的とした農作物が作出されてきている。

平成18年 8 月 15 日現在, 日本では厚生労働省による安 全性審査の手続きを経た遺伝子組換え作物は76品目に達 している2)。行政サイドでは, 農林水産省・環境省によ り環境への安全性や, 内閣府食品安全委員会・厚生労働 省による食品としての安全性などが科学的に審査され， 安全が確認された農作物やこれらを原料とした食品は食 べて安全としているが，一部市民団体などからは本当に 安全であるのか? という反論も激しく, これら食品の安 全性に関して賛否両論が出され国民の間でのコンセンサ スが得られていない状態が続いている。つまり, 科学的 
に「安全」と認められても，一般社会では心理的な「安 心」が得られていない。大多数の国民が，遺伝子組換え 農作物や食品に不安感があるとしている。店頭では「遺 伝子組換え」と表示した食品を実際に見ることはほとん ぞないのが現状である。

そこで, 遺伝子組換え農作物を栽培・生産する可能性 のある農業従事者から，その農作物を用いて商品開発を 行う食品開発者, その商品を流通・販売する流通業者, そして最後に購入消費する一般消費者の各階層。すなわ ち, 遺伝子組換え農作物を生産から消費段階において関 わる可能性のある者を対象に, 食品に関わる立場の違い から, 遺伝子組換え技術や食品について, 意識調査を行 った。その結果から各立場による理解度や認識度の相違 を把握し, 遺伝子組換え農作物に関わる情報の共有化を 図ることによって，相互理解への足がかりを得ることを 本研究の目的とした。

\section{II. 方 法}

意識調査は, 食料生産, 食品開発, 流通, 一般消費の 各分野について調査を行った。対象の選定は, 食料生産 では関東および関西の市町村レベルの農業協同組合に協 力を依頼して, 農業従事者（以下生産者と略す）を対象 に調査を実施した。郵送により自記式調査票（質問数30 問）を送付し，調査数は91名（調査票の回収率は91.0\%） でうち男性は56名（平均年齢43.9歳），女性は35名（平 均年齢 41.9 歳) あった。また, 食品開発 (以下企業と略 す）は東証及び大証の一部上場企業であり, かつ, 食品 研究開発部門を持つ食品企業（20社）を対象に調査を実 施した。生産者と同様に調査票を郵送し, 調査数は187 名（調査票の回収率は93.5\%）でうち男性は123名（平 均年齢 37.2 歳)，女性は64名（平均年齢31.1歳）あった。 流通業者（以下流通と略す）は大阪府及び兵庫県内の生 活協同組合 4 組合を対象に生産者と同様に調査票を郵送 し, 調査数は31名（調査票の回収率は $77.5 \%$ ）でうち男 性は10名 (平均年齢44.8歳), 女性は21名 (平均年齢 39.2 歳）あった。一般消費者（以下消費者々略す）は本 学学生の保護者を対象に調査票を配布し, 調査数は62名 （調査票の回収率は95.4\%）でうち男性は 2 名（平均年

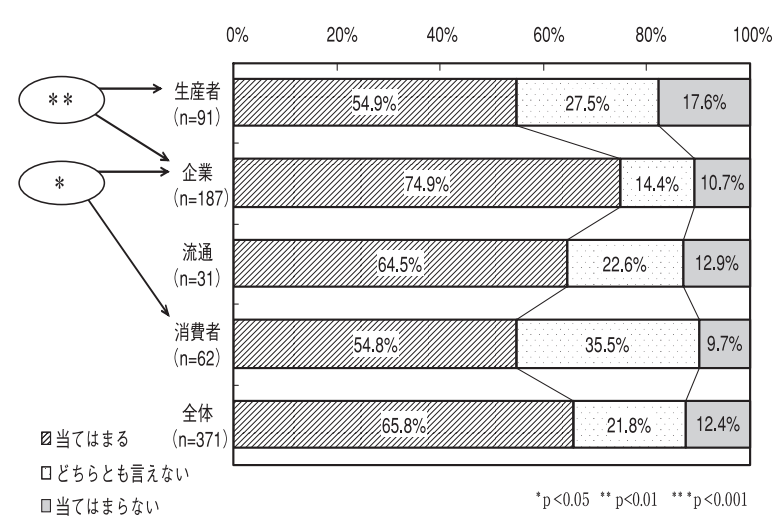

図 1 遺伝子組み換え技術への関心
齢50.0歳), 女性は60名 (平均年齢47.6歳) あった。 各質問の回答肢は，(1)非常に当てはまる，(2)かなり当 てはまる，(3)やや当てはまる，(4)どちらとも言えない, (5)やや当てはまらない，(6)かなり当てはまらない，(7)非 常に当てはまらない,の 7 段階から最も適当なものを択 一選択とした。統計的解析にあたって, これらのカテゴ リは(1)〜(3)を(1)当てはまる，(4)を(2)どちらとも言えない， (5)〜(7)を(3)当てはまらない, の3つのカテゴリに再順序 化を行った。また，各变数間の有意性の検定について， 設問間の関連性はカイ二乗検定を行い, 設問間のカテゴ リ別の比較は Kruskal-Wallis 検定, 群別およびカテゴ リ別の多重比較は Mann-Whitney 検定を行った。なお, 多重比較の有意確率は Bonferroni の不等式による修正 を行った。さらに, 多变量間の共通因子の抽出を目的に 主成分分析法による多变量解析を行った。主成分分析を 適用するにあたっては, 前述の各設問のカテゴリ順序を 調整した。成分抽出はその累積寄与率を概ね70\%を目安 とし, 抽出成分の回転はバリマックス回転（直交回転） を行った。得られた成分は成分得点として変数に保持し， その成分得点の信頼性はクロンバック $\alpha$ 係数を用いて確 認を行った。

\section{III. 結 果}

\section{1. 食の安全性および遺伝子組換え食品と技術について の関心度}

食べ物に関する関心度は全体で $93.4 \%$ の者が関心を示 しており, 消費者群は $93.7 \%$, 流通群は $96.9 \%$, 企業群 は94.6\%, 生産者群では93.0\%と4 群いずれも関心が高 い傾向を示した。また，オーガニック食品への関心度は 全体で58.2\%の者が関心を示して抢り，消費者群は 69.2 $\%$, 流通群は $71.1 \%$, 企業群は $62.4 \%$, 生産者群では $37.0 \%$ と生産者群を除いた 3 群で関心が高い傾向を示し た。また, 遺伝子組換え技術への関心度は消費者群が $54.8 \%$ と低く, 続いて流通群の $64.5 \%$ となり, 企業群は $74.9 \%$ で 4 群のうちで最も関心が高い傾向を示した。生 産者群と企業群間（ $\mathrm{p}=0.001, \mathrm{p}<0.01)$ および企業群 と消費者群間（ $\mathrm{p}=0.01, \mathrm{p}<0.05)$ で有意差がみられ た（図 1 )。また, 遺伝子組換え食品への関心度は生産

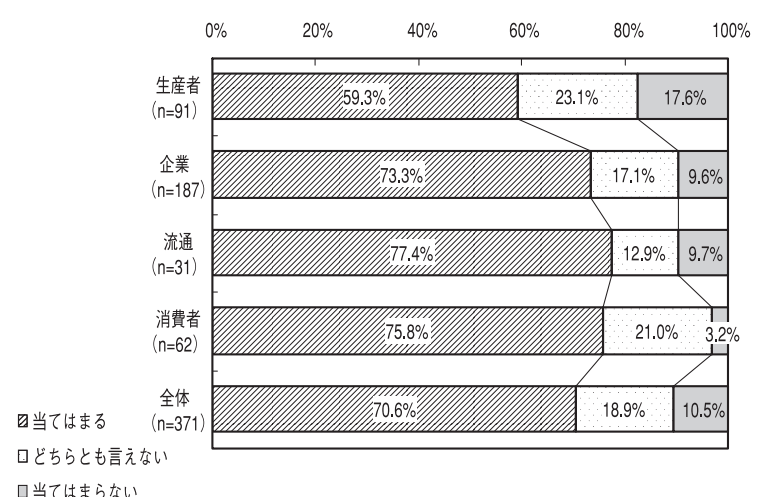

図 2 遺伝子組み替え食品への関心 
者群では関心のある割合が59.3\%であり，他の 3 群に比 ベて関心が低い傾向を示した（図 2 ）。遺伝子組換え食 品への関心度は遺伝子組換え技術へのそれと比較して, 生産者群と企業群はほぼ同じ割合であるのに対し, 消費 者群は 4 群のなかで最も関心が高く, 消費者群は遺伝子 組換え技術より遺伝子組換え食品に関心が強いと考えら れた。

\section{2. 食糧生産への遺伝子組換え技術}

食糧生産への遺伝子組換え技術の適用に関しては, 全 体では $36.7 \%$ 者が賛成しており，そのうち，企業群は 賛成する割合が $51.3 \%$ と他の 3 群に比べて多かった。生 産者群と企業群間（ $\mathrm{p}=0.000, \mathrm{p}<0.001)$ 抢よび企業 群と消費者群間（ $\mathrm{p}=0.000, \mathrm{p}<0.001)$, さらに，生産 者群と流通群間（ $\mathrm{p}=0.000, \mathrm{p}<0.001 ）$ で有意差がみ られた（図 3 ）。をた，食糧生産への遺伝子組換え技術 研究の賛否に関しては, 全体では $60.9 \%$ 者が研究に賛 成して抢り, 続いて, 企業群と流通群が多く, 消費者群 は 4 群のうちで最も賛成の割合が低い傾向を示した。生 産者群と企業群間 $(\mathrm{p}=0.000, \mathrm{p}<0.001)$ 抢よび企業 群と消費者群間（ $\mathrm{p}=0.000, \mathrm{p}<0.001)$, さらに, 生産 者群と流通群間（ $\mathrm{p}=0.001 ， \mathrm{p}<0.01 ）$ で有意差がみら れた（図 4 )。このことから, 食糧生産への遺伝子組換 え技術の研究には賛成であるが，実際の適用には慎重な

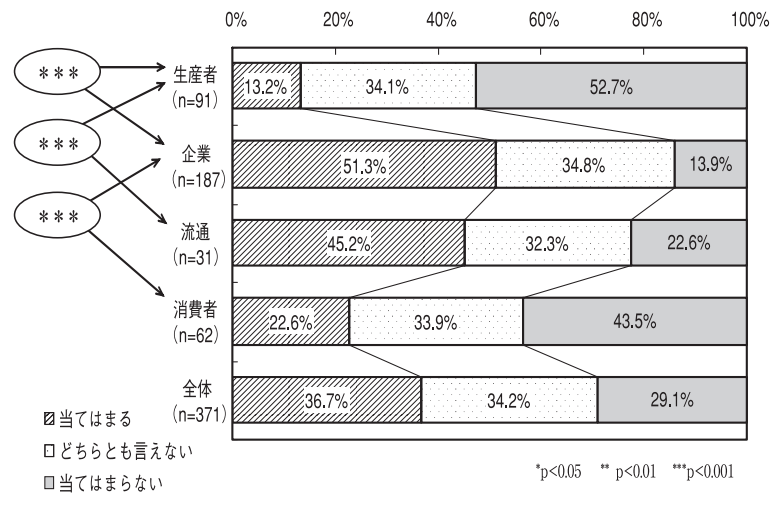

図 3 食糧生産に遺伝子組み換え技術を適用することに賛成

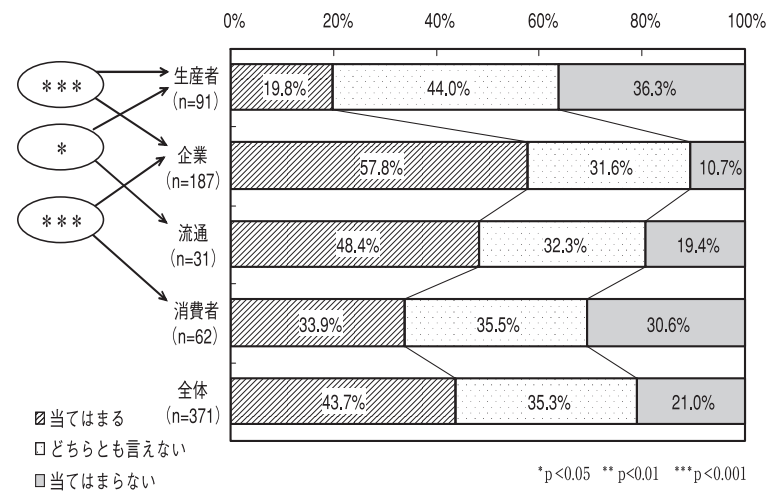

図 5 食糧生産に遺伝子組み換え技術を用いることは, 環境や 私達に利益を提供する
者が多いと考えられる。食糧生産への遺伝子組換え技術 の適用および研究に賛成する人の割合は，企業群，流通 群，消費者群，生産者群の順で多かった。特に，企業・ 流通群々生産者・消費者群で食糧生産への遺伝子組久換 え技術の適用や研究に抢ける認識の相違がみられる。

また，食糧生産への遺伝子組換え技術の適用が環境や 人に対しどのような影響があるかについては，「利益を 提供する」と考える者の割合は全体では $43.7 \%$ であり， 4 群で最も高い割合を示したのは企業群の $57.8 \%$ であっ た。生産者群と企業群間（ $\mathrm{p}=0.000, \mathrm{p}<0.001)$ およ び企業群と消費者群間（ $\mathrm{p}=0.000, \mathrm{p}<0.001)$ ，さらに， 生産者群と流通群間（ $\mathrm{p}=0.005, \mathrm{p}<0.05)$ で有意差が みられた（図 5 )。一方，「有害である」と考える者の割 合は全体では $24.5 \%$ であり，4 群で最も高い割合を示し たのは消費者群の $41.9 \%$ となった。生産者群と企業群間 $(\mathrm{p}=0.000, \mathrm{p}<0.001)$ および企業群と消費者群間（ $\mathrm{p}$ $=0.000, \mathrm{p}<0.001)$, 生産者群と流通群間 $(\mathrm{p}=0.000$, $\mathrm{p}<0.001)$, 流通群と消費者群間（ $\mathrm{p}=0.000, p<0.001)$ で有意差がみられた（図 6 )。「利益を提供する」と「有 害である」は 4 群間で相反する認識であると考えられる。 さらに，環境や人に対し有害であると考える者の割合が， 生産者群, 消費者群, 流通群, 企業群の順で多い傾向を 示した。

この点に関しても, 企業・流通群と生産者·消費者群

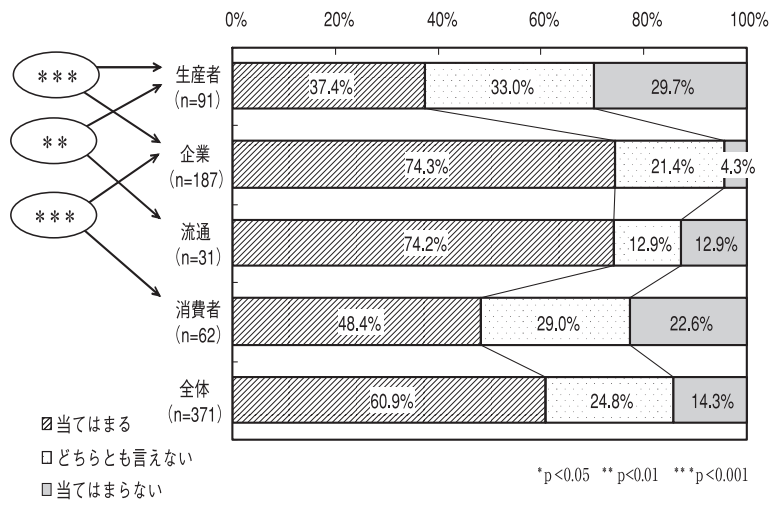

図 4 食糧生産に遺伝子組み換え技術を研究することに賛成

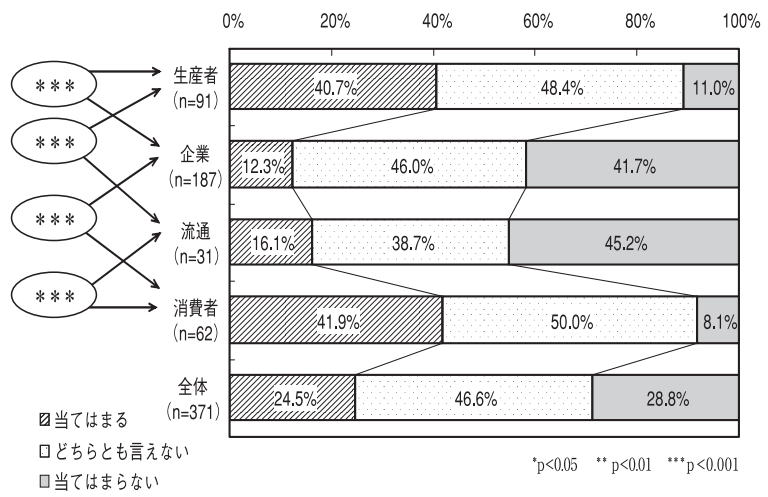

図 6 食糧生産に遺伝子組み換え技術を用いることは, 環境や 私達に有害である 
で大きく傾向が分かれることが示された。生産者・消費 者群は，「利益を提供する」に賛成する者の割合よりも 「有害である」とする者の割合が低い傾向を示した。一 方，「利益を提供する」に賛成する者の割合よりも，「有 害である」とする者の割合が高い傾向を示した。また， 企業・流通群も，「利益を提供する」に賛成する者の割 合よりも，「有害である」とする者の割合が低い傾向を 示したが，「利益を提供する」に反対する者の割合と 「有害である」とする者の割合はほぼ同程度であった。 これらから, 生産者・消費者群は, 企業・流通群に比べ て遺伝子組換え技術の適用に否定的な心情が強いと考え られる。

\section{3．食糧生産以外への遺伝子組換え技術}

食糧生産以外への遺伝子組換え技術の環境や人に対す る影響について，企業群では「利益を提供する」に賛成 する者の割合が $62.0 \%$ と多く見られたが，その他の 3 群 では $26.2 \%$ から $41.9 \%$ と低い傾向を示した。生産者群と 企業群間（ $\mathrm{p}=0.000 ， \mathrm{p}<0.001 ）$ 打よび企業群と消費 者群間（ $\mathrm{p}=0.000 ， \mathrm{p}<0.001 ）$ で有意差がみられた (図 7 )。また，「有害である」とする者の割合は，生産 者・消費者群が多い傾向を示したのに対して企業・流通 群は低かった。生産者群々企業群間（ $\mathrm{p}=0.000, \mathrm{p}<$ $0.001 ）$ 抢よび企業群と消費者群間（ $\mathrm{p}=0.000, \mathrm{p}<$ $0.001)$ ，生産者群と流通群間（ $\mathrm{p}=0.000, \mathrm{p}<0.001)$ ， 流通群と消費者群間（ $\mathrm{p}=0.000 ， \mathrm{p}<0.001 ）$ で有意差 が反られた（図８）。ここでも，生産者・消費者群と企 業・流通群間で認識の違いが浮き彫りとなった。

しかし，食糧生産以外での遺伝子組換え技術の適用に 関しては企業群と生産者・流通・消費者の 3 群にとって は，あまり情報がなくイメージしにくい面があったと考 えられる。

食糧生産（図 5 および図 6 ） と食糧生産以外（図 7 抒 よび図 8 ）に抢ける遺伝子組換え技術の適用に関する 「利益提供性」と「有害性」を比較すると全体的にはほ ぼ同傾向を示したが，企業群が食糧生産以外に対する技 術の適用に好意的であったのに対して, 消費者群では否

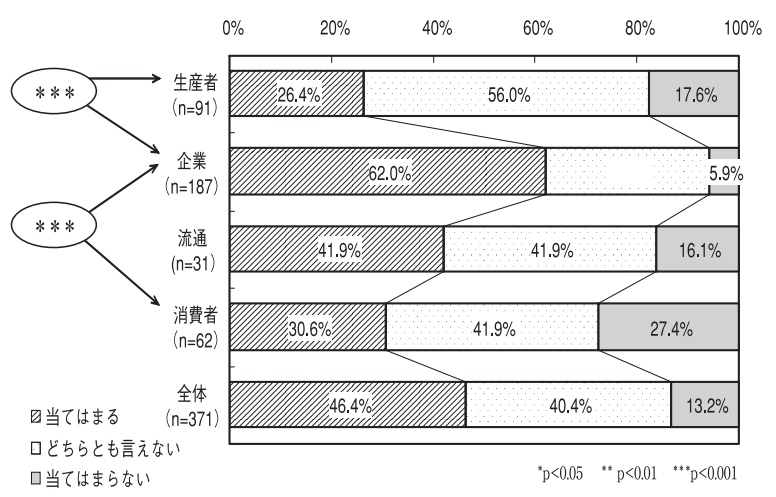

図 7 一般に遺伝子組み換え技術を用いることは，環境や私達 に利益を提供する
定的な傾向が認められた。このことから，消費者にとっ て食糧への適用に関する情報に比へ，食糧生産以外への 適用に関する情報が少ないことが，遺伝子組換え技術の 適用に関する「利益提供性」と「有害性」の認識に関係 する要因の一つであると推察される。

\section{4．食物関連情報の信頼性と情報源としての責任}

食物関連の危険に関連する情報の信頼性については, 「新聞は信頼できる」とする者の割合は，全体では 34.8 \%，4 群で最も信頼する割合が高いのは消費者群の64.5 $\%$, 続いて, 生産者群 $42.9 \%$ となり, 企業群 $24.1 \%$ と流 通群 $16.1 \%$ と低い傾向を示した。生産者群と企業群間 （ $\mathrm{p}=0.000 ， \mathrm{p}<0.001 ）$ 打よび企業群と消費者群間（ $\mathrm{p}$ $=0.000, \mathrm{p}<0.001)$, 生産者群と流通群間（ $\mathrm{p}=0.001$, $\mathrm{p}<0.01)$ ，流通群と消費者群間（ $\mathrm{p}=0.000, \mathrm{p}<0.001)$ ， 生産者群と消費者群間（ $\mathrm{p}=0.007, \mathrm{p}<0.05 ）$ で有意差 がみられた（図 9 )。「農林水産省は信頼できる」とする 者の割合は「厚生労働省」抢よび「大学の研究者」と 4 群間で差異は見られるもののほぼ同傾向であり，全体で は $49.3 \%$, 最も信頼する群は消費者群で $62.9 \%$ となり, 続いて, 流通群が $54.8 \%$, 企業群が $46.5 \%$, 生産者群が $44.0 \%$ となった（図10)。

情報源の信頼性として 4 つのうちで, 顕著に差が見ら れたのは「新聞」からの情報であった。消費者群は新聞 の情報を信頼できる割合が高いのに対して，流通群と企 業群では信頼できる割合は高くない傾向を示した。また， 「大学の研究者」の情報を信頼できるとする者の割合が 消費者群で高い傾向を示した。しかし，農林水産省など 行政への信頼性は, 生産者群が低く, 消費者群が高い傾 向が見られたが有意な差ではなかった。

さらに，食物に関する情報公開の責任については， 「新聞は責任を負っている」とする者の割合は，全体で は51.5\%，4 群で最も「責任を負っている」とする割合 が高いのは消費者群の $58.1 \%$, 続いて, 企業群が $51.9 \%$, 流通群の $48.4 \%$ と生産者群の $47.3 \%$ とほぼ同程度の割合 を示した（図11）。「厚生労働省」「農林水産省」「大学の 研究者」の責任に関しては,「大学の研究者」の責任を

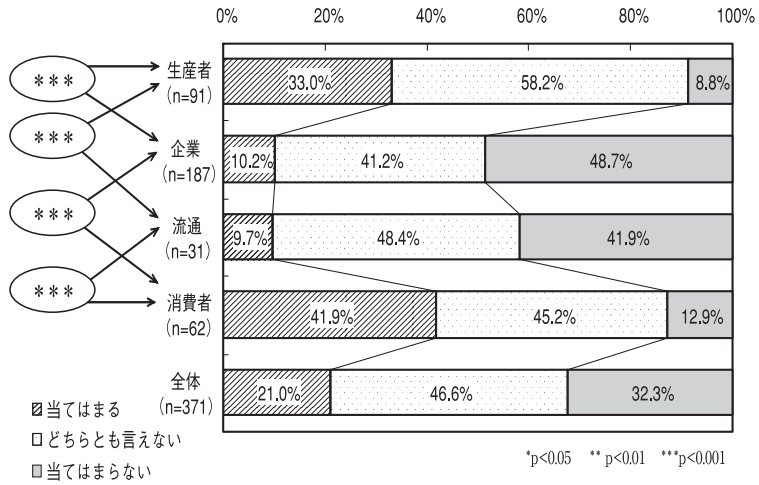

図 8 一般に遺伝子組み換え技術を用いることは, 環境や私達 に有害である 


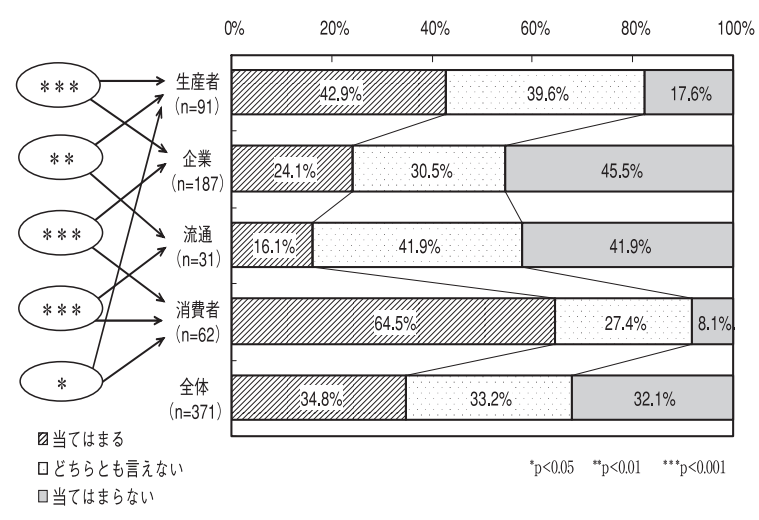

図 9 新聞の食物関連の危険に関する情報は信頼できる

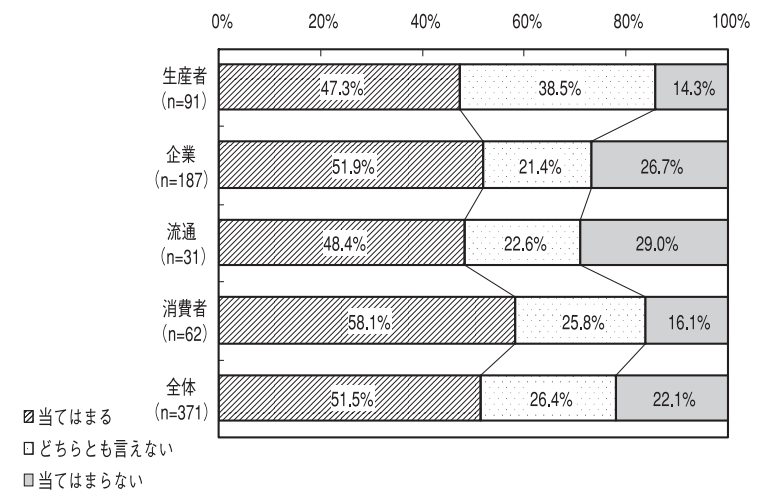

図11 新聞は良い食物関連の情報を公開する責任を負っている

負う割合が「農林水産省」抢よび「厚生労働省」に比べ て，10ポイント程度低い割合を示しているものの，「農 林水産省」に抢䦻傾向と同傾向を示した。「農林水産 省」が情報公開の責任を負うとする者の割合は, 全体で 80.3\%と「新聞」に比べて高い割合を示した。 4 群間で は, 流通群が $87.1 \%$ と最も高く, 続いて, 企業群が 86.1 $\%$, 消費者群の $75.8 \%$ となった。生産者群は $69.2 \%$ と最 も低い割合を示した。生産者群と企業群間（ $\mathrm{p}=0.001$, $\mathrm{p}<0.01$ ) で有意差が 「新聞」に対する責任度が低く,「農林水産省」(厚生労 働省）などの行政機関に責任を強く求める傾向があった。 しかし, 生産者群は行政への不信感から期待度が低い傾 向を示した。

\section{5. 遺伝子組換えに関する設問間の共通成分の抽出}

これまで, 遺伝子組換え技術や食品の適用や研究とそ れらへの信頼。また, 適用や研究で得られる利益や発生 する責任。さらに, 弊害や不都合について, 生産者, 企 業, 流通, 消費者のそれぞれの立場の相違を比較検討し た。ここでは, 設問間の関連性や主要な成分の抽出を目 的に多変量解析の一手法である主成分分析を行った。そ の結果， 5 つの主成分が抽出された。 5 つの主成分の信 頼性の指標であるクロンバック $\alpha$ 係数は $0.9 \sim 0.7$ を示し た。また，第 5 主成分までの累積寄与率は $72.1 \%$ となり，

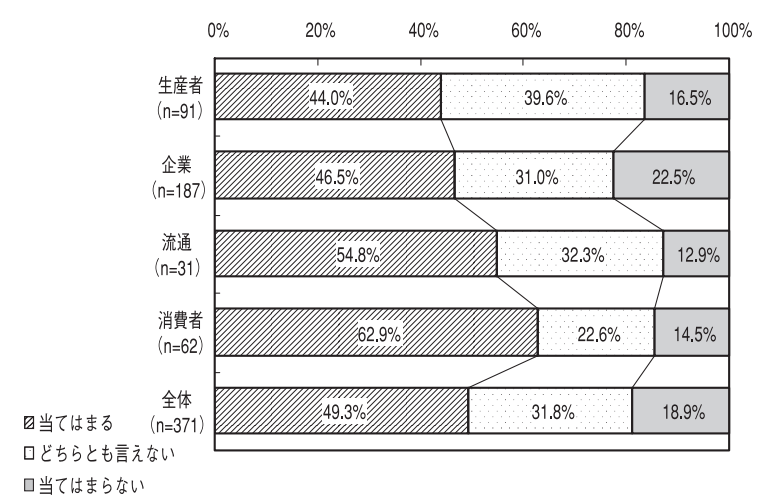

図10農林水産省の食物関連の危険に関する情報は信頼できる

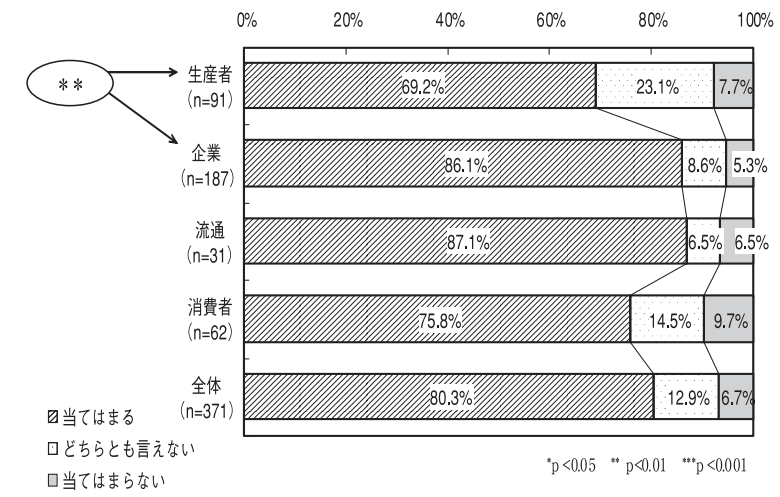

図12 農林水産省は良い食物関連の情報を公開する責任を負っ ている

成分抽出に扔いて妥当な結果と考えられる。第 1 主成分 は遺伝子組換え技術の適用や研究, さらに, それによる 利益提供などの設問項目の成分負荷量が高く見られたこ とから，有用性・正当性に関連する成分とした。また， 第 2 主成分は食物関連の危険に関する情報源としての正 確性や信頼性などの設問項目の成分負荷量が高いことか ら, 情報の信頼性に関連する成分とした。さらに, 第 3 主成分は情報源の責任に関する設問項目と高い成分負荷 量を示したことから，責任に関連する成分とした。続い て, 第 4 主成分は食糧生産やそれ以外の遺伝子組換え技 術を適用することに伴う弊害や有害性に関する設問項目 と高い成分負荷量を示したことから, 弊害に関する成分 とした。最後に, 第 5 主成分は遺伝子組換え食品や技術 への関心に関する設問項目と高い成分負荷量を示したこ とから，関心に関する成分と定義した（表 1 ）。

次に, 抽出した 5 つの主成分を成分得点化して, 生産 者・流通・企業・消費者の 4 群と比較した。第 1 主成分 である有用性と正当性では, 企業群と生産者群間（ $\mathrm{p}=$ $0.000, \mathrm{p}<0.001)$ 。企業群と消費者群間（ $\mathrm{p}=0.000, \mathrm{p}$ $<0.001)$ 。流通群と生産者群間（ $\mathrm{p}=0.001, \mathrm{p}<0.01)$ 。 流通群と消費者群間（ $\mathrm{p}=0.014, \mathrm{p}<0.05)$ でそれぞれ 有意差を示した。企業群が最も高く, 続いて, 流通群と なった。企業群は遺伝子組換えについて有用性や正当性 を 4 群のうちで最も高く評価している。一方, 有用性や 


\begin{tabular}{|c|c|c|c|c|c|}
\hline & 第1主成分 & 第2主成分 & 第3主成分 & 第4主成分 & 第 5 主成分 \\
\hline 食糧生産に遺伝子組み換え技術を適用することは賢明だ & 0.879 & 0.010 & 0.011 & -0.180 & -0.027 \\
\hline 食糧生産に遺伝子組み換え技術を適用することには賛成だ & 0.875 & 0.095 & 0.001 & -0.156 & -0.014 \\
\hline 食糧生産に遺伝子組み換え技術を適用することは正しいことだ & 0.864 & 0.046 & -0.032 & -0.110 & -0.018 \\
\hline 食糧生産に遺伝子組み換え技術を研究することは賢明だ & 0.861 & 0.022 & 0.124 & -0.102 & 0.128 \\
\hline 食糧生産に遺伝子組久換え技術を研究することには賛成だ & 0.858 & 0.034 & 0.118 & -0.174 & 0.102 \\
\hline 食糧生産に遺伝子組み換え技術を研究することは正しいことだ & 0.853 & 0.047 & 0.094 & -0.070 & 0.106 \\
\hline $\begin{array}{l}\text { 食糧生産に遺伝子組み換え技術を用いることは, 環境や私自身や私に } \\
\text { とって大切な人たちに, 大きな利益を提供する }\end{array}$ & 0.851 & 0.005 & -0.002 & -0.147 & 0.043 \\
\hline $\begin{array}{l}\text { 食糧生産に遺伝子組み換え技術を用いることは, 環境や私自身や私に } \\
\text { とって大切な人たちに, 都合がよい }\end{array}$ & 0.834 & 0.053 & 0.021 & -0.102 & 0.030 \\
\hline $\begin{array}{l}\text { 一般に遺伝子組み換え技術を用いることは，環境や私自身や私にとっ } \\
\text { て大切な人たちに，都合がよい }\end{array}$ & 0.715 & 0.016 & 0.055 & -0.327 & 0.071 \\
\hline $\begin{array}{l}\text { 一般に遺伝子組み換え技術を用いることは, 環境や私自身や私にとっ } \\
\text { て大切な人たちに，大きな利益を提供する }\end{array}$ & 0.711 & -0.034 & 0.056 & -0.340 & 0.070 \\
\hline 農林水産省の食物関連の危険に関する情報は，正確だ & 0.093 & 0.898 & 0.069 & -0.046 & 0.054 \\
\hline 農林水産省の食物関連の危険に関する情報は, 信頼できる & 0.105 & 0.875 & 0.015 & -0.158 & -0.043 \\
\hline 厚生労働省の食物関連の危険に関する情報は，正確だ & 0.103 & 0.861 & 0.062 & -0.062 & 0.030 \\
\hline 厚生労働省の食物関連の危険に関する情報は, 信頼できる & 0.144 & 0.861 & 0.009 & -0.158 & -0.036 \\
\hline 新聞の食物関連の危険に関する情報は，正確だ & -0.177 & 0.771 & -0.041 & 0.153 & 0.070 \\
\hline 大学の研究者の食物関連の危険に関する情報は，正確だ & 0.069 & 0.769 & 0.098 & 0.083 & 0.141 \\
\hline 大学の研究者の食物関連の危険に関する情報は, 信頼できる & 0.073 & 0.753 & 0.057 & 0.030 & 0.094 \\
\hline 新聞の食物関連の危険に関する情報は，信頼できる & -0.184 & 0.747 & -0.017 & 0.141 & 0.054 \\
\hline 農林水産省は，良い食物関連の情報を公開する責任を負っている & 0.108 & 0.042 & 0.928 & -0.043 & 0.062 \\
\hline 厚生労働省は，良い食物関連の情報を公開する責任を負っている & 0.116 & 0.041 & 0.914 & -0.035 & 0.040 \\
\hline 大学の研究者は, 良い食物関連の情報を公開する責任を負っている & 0.004 & 0.055 & 0.827 & 0.003 & 0.124 \\
\hline 新聞は，良い食物関連の情報を公開する責任を負っている & 0.009 & 0.047 & 0.680 & 0.103 & 0.003 \\
\hline $\begin{array}{l}\text { 一般に遺伝子組み換え技術を用いることは，環境や私自身や私にとっ } \\
\text { て大切な人たちに，不都合である }\end{array}$ & -0.480 & 0.004 & 0.011 & 0.794 & -0.032 \\
\hline $\begin{array}{l}\text { 一般に遺伝子組み換え技術を用いることは，環境や私自身や私にとっ } \\
\text { て大切な人たちに，有害である }\end{array}$ & -0.505 & 0.031 & 0.031 & 0.782 & -0.011 \\
\hline $\begin{array}{l}\text { 食糧生産に遺伝子組み換え技術を用いることは, 環境や私自身や私に } \\
\text { とって大切な人たちに, 有害である }\end{array}$ & -0.560 & 0.005 & 0.059 & 0.673 & -0.010 \\
\hline $\begin{array}{l}\text { 食糧生産に遺伝子組み換え技術を用いることは, 環境や私自身や私に } \\
\text { とって大切な人たちに，不都合である }\end{array}$ & -0.586 & -0.041 & 0.031 & 0.671 & -0.008 \\
\hline 遺伝子組み換え食品に関心がある & 0.239 & 0.054 & 0.032 & 0.038 & 0.849 \\
\hline 遺伝子組久換え技術に関心がある & 0.293 & 0.015 & -0.008 & -0.069 & 0.807 \\
\hline 食べ物に関心がある & -0.081 & 0.084 & 0.055 & -0.143 & 0.625 \\
\hline オーガニック食品に関心がある & -0.065 & 0.098 & 0.111 & 0.120 & 0.593 \\
\hline クロンバック $\alpha$ 係数 & 0.959 & 0.929 & 0.861 & 0.938 & 0.720 \\
\hline 寄与率 ～～～～～～～～～～～ & 27.907 & 18.054 & 9.778 & 8.917 & 7.435 \\
\hline 累積寄与率 & 27.907 & 45.961 & 55.739 & 64.655 & 72.091 \\
\hline
\end{tabular}

正当性を評価していない群は消費者群となり，最も評価 していない群は生産者群であった（図13）。第 2 主成分 である情報の信頼性では, 企業群と消費者群間（ $\mathrm{p}=$ $0.000, \mathrm{p}<0.001)$ 。企業群と生産者群間（ $\mathrm{p}=0.002, \mathrm{p}$ <0.01）でそれぞれ有意差を示した。情報の信頼性は消 費者群が最も信頼しており, 続いて, 生産者群となり, 企業群は 4 群で最も情報の信頼性を低く評価している (図13)。

第 3 主成分である遺伝子組換えに関する責任の所在に
ついて, 流通群が最も高く責任の所在を認識している。 その他の 3 群は同程度の認識に留まっているが, 有意性 は認められなかった（図13）。第 4 主成分である遺伝子 組換えに関する弊害については, 企業群と生産者群間 $(\mathrm{p}=0.000, \mathrm{p}<0.001)$ 。企業群々消費者群間（ $\mathrm{p}=$ $0.000, \mathrm{p}<0.001)$ 。流通群と生産者群間 $(\mathrm{p}=0.007, \mathrm{p}$ $<0.01)$ 。流通群と消費者群間（p=0.000, $\mathrm{p}<0.01 ）$ でそれぞれ有意差を示した。遺伝子組換えの弊害を認識 している群で, 最も高いのは消費者群であり, 続いて生 


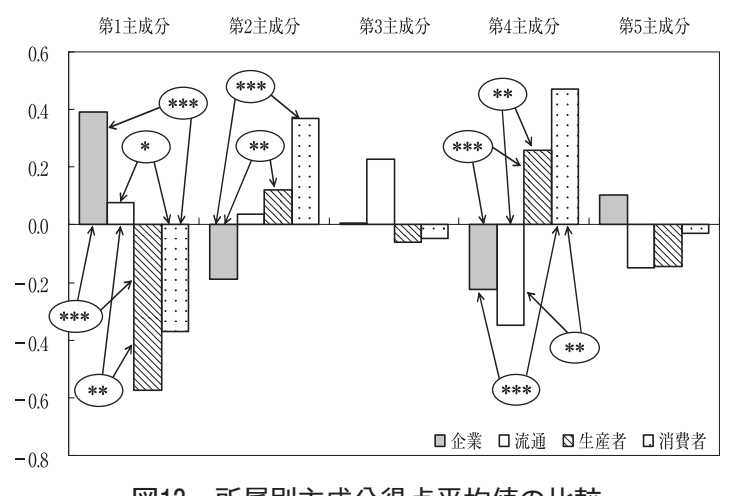

図13 所属別主成分得点平均値の比較

産者群であった。弊害を認識していない群では, 流通群 であり続いて企業群となった。第 1 主成分の有用性と正 当性とは成分得点分布が 4 群間で大きく相違しており, それぞれの立場の違いを特徵付けるものであり興味深い。 第 5 主成分である遺伝子組換えへの関心については, 4 群の成分得点分布に大きな違いは見られず，いずれの 群間とも有意性はなかった。

\section{N. 考察}

今回の調査研究の結果, 生産者・消費者群と企業·流 通群の間, 特に生産者群と企業群に遺伝子組換え技術に 関して感じ方・考え方で大きな隔たりが見られた。世界 的に遺伝子組換え作物の商業栽培実績が増えているなか, 食糧自給率が低い日本においてこのギャップをどう考え るのか, つまり, 遺伝子組換え技術や食品についての国 民のコンセンサスをどう構築していくのかが早急に迫ら れている状況となってきている。すでに遺伝子組換え農 作物は日本の食卓に上がっていると言われている。加工 食品の中に含まれている場合もあるし，混入率が $5 \%$ 未 満なら「遺伝子組換え○○使用」と法的には表示しなく てよいことになっている。また，人が直接摂食しなくて も，家畜の飼料として輸入されているものもある。また， 「遺伝子組換え農作物を選ばない権利」や「知る権利」 が侵害されていることに対して，不安を感じている33。 行政は従来の食品と同様に, 食べて安全であると説明し ているが，一部の消費者は，安全性が証明されていない と考え，何が抢きるかわからないと反論している。この ような対立関係を見るにつれ，多くの国民はますます不 安に拍車をかける状態となっている4)。これらのことは, 今回の主成分分析において遺伝子組換え技術や食品への 正当性や有用性と考えられる第 1 成分として抽出され, 各群間の成分得点について有意性が認められており, 遺 伝子組換え技術や食品に対する正当性や有用性水準が立 場の違いで明確に現れている。すなわち，企業では積極 的に正当性や有用性を評価しているが，消費者と生産者 では遺伝子組換えに関わる技術や食品に対して消極的に 捉えている。特に, 生産者群では農作物を生産する立場 として慎重に対処する姿勢としてみることができる一方
で，技術導入に打ける経済的効果が不透明な状況も要因 として存在すると考えられる。

信頼できる情報源として，「新聞」「厚生労働省」（農 林水産省, 大学の研究者）などがその役割を担う必要が あると考えられるが，今回の結果からは全体として約50 \%の者しか信頼していない（図10）。また，主成分分析 で第 2 主成分として抽出された情報の信頼性・正確性の 成分得点が最も高かったのは消費者であったが，これら は消費者が新聞に期待することの表れと見ることができ る。その他の群では「新聞」に対しての信頼性や責任性 に対して低い評価であった。企業·流通群は, 日頃, 食 品の研究開発や流通販売に携わっており, 食品に関する 知識が豊富である。新聞記事には正しい情報もあればニ ュースバリューを求めるあまり正しい情報を与えていな いものも含まれていると感じていることが一因となって， 新聞に対する評価が低かったと考えられる。正しい情報 とは, 科学的根拠に則った情報であるとここでは定義す るが, 今まで「厚生労働省」(農林水産省, 大学の研究 者）は，国民の視点に立って情報を伝えてきたとは言い 難い。それは図11抢よび図12を比較しても明らかである。 いずれの対象についても，信頼できる情報源であると答 えた割合に対して, 情報公開への責任があると答えた割 合が高かったことより，これまで情報伝達がうまく機能 してなかったと考えられる。行政サイドではホームペー ジなどでの広報活動を行っているし, 国民の不安を少し でも解消しようと遺伝子農作物の検査技術の向上に努力 もしている5)。また, 試験栽培に関する条例づくりに対 して多くの立場の市民と意見を交えて合意形成に涙ぐま しい努力をしている大学研究者もいる6)。ただ，多くの 国民層にこれらの状況や事実は知られていない。そして 食糧生産以外への遺伝子組換え技術の応用に関する情報 は, 食品ほど身近な存在ではないため, 多くの国民が共 有する情報は乏しい。

このような共有すべき情報の不足は, 今回の主成分分 析において, 第 4 成分として抽出された遺伝子組換えに 関して弊害と考えられる成分得点の各群の相違点から明 らかである。弊害の成分得点が最も高かったのは消費者 群であった。また, 前述の第 1 成分においても消費者は 有意に低い成分得点を示しており，このことは遺伝子組 換えに関する情報について, 消費者や生産者は有用性や 正当性などに否定的な姿勢を示し, 利益性や便宜性につ いてもマイナスイメージを持っている。特に, 生産者は 遺伝子組換えに関する情報のうち技術や研究を不透明な ものとして捕らえていると言える。また，消費者は食料 生産はもちろんのこと, それ以外の遺伝子組換えに関し て否定的な姿勢を示している。これらのことは生産者や 消費者が遺伝子組換えに関して高い関心を持っているこ とに他ならない。今日的課題として, 生産者や消費者に 対して, 正しい情報を広く深く伝える必要があると考え られる。新聞をはじめとするメディア, 行政, 大学等研 
究者は, 地道に情報交換・コミュニケーションの機会を 拡げていく責任があるのは当然であるが，同時にこれら の立場にフリーの組織, 例えば NPO 法人などの協力も 得て，多くの国民層を巻き込んだ形での情報の共有化を 図ることも必要と考えられる。

このように，遺伝子組換えに関する正当性や有用性お よび弊害への関心度が立場の違いによって認識の相違が みられたことは，それらの食品や技術を開発，生産，流 通, 消費の各段階で相互に理解を深めて, 消費者へは不 安感を払拭するために, また, 生産者には安全性確保や 利益性に関して，情報を提供する側と情報交換を積極的 に行うことが必要であると考えられる。

ここでいう情報の共有化とは，全ての国民が同じ考え を持つことを意味していない。遺伝子組換え技術や食品 に関して全ての国民層，それが無理ならば少なくとも遺 伝子組換え食品に関与する可能性のある生産者, 企業, 流通，消費者が同じ状況で考えることができる情報を持 つということである。今回の調査では明らかに生産者. 消費者群と企業・流通群に大きな違いが見られたが，こ れは生産者や消費者にとって組換え技術や食品に関して 判断できる情報があまり多くなかったことが大きな原因 と考えられる。現に，感想・コメント欄に「質問の意味 がわからない」や「質問が難しすぎる」との記載が見ら れた。今回の生産者・消費者群と企業・流通群の間での 乘離が，単に情報不足によるものか，あるいは同じ情報 を与えられた場合でも考え方や感じ方に差があるものな のか興味深いところである。近い将来，遺伝子組換え食 品を食べざるを得ない状況になることが予想されている ので，今一度，多くの国民に「遺伝子組換え技術」につ いて考える必要があろう。その意味でも同じレベルの情 報を共有しあうことが契緊の課題であると考えられる。

\section{V. 要 約}

遺伝子組換え農作物を栽培・生産する可能性のある農 業従事者（生産者群）から，その農作物を用いて商品化 する食品開発者（企業群），商品を流通・販売する流通 業者 (流通群)。そして, 最後に購入消費する一般消費 者（消費者群）の各立場から，遺伝子組換え農作物を生 産から消費までの 4 群間で，食品に関わる立場の違いで 遺伝子組換え技術や食品について，ぞう感じ受けとめて
いるか，意識調査を行った。その結果，以下のことが示 唆された。

(1) 企業群は他群に比べて, 遺伝子組換え技術に関心 があったが，消費者群は技術より遺伝子組換え食品 に関心があった。

(2) 食糧生産または食糧生産以外に遺伝子組換え技術 を適用することは有害だ，と思う者の割合は，食糧 生産または食糧生産以外のいずれに対しても生産者 群, 消費者群, 流通群, 企業群の順で多かった。

(3) 遺伝子組換え技術の有用性と弊害の認識で, 生産 者群・消費者群と企業群・流通群で明らかな相違が みられた。

(4) 信頼できる情報源として，新聞に対する評価が， 他の行政や大学の研究者に比べて低く, その傾向は, 企業群・流通群で顕著であった。

(5) 情報公開への責任はどの機関に対しても求めてお り，多くの国民層に対して，地道に情報交換・コミ ュニケーションの機会を拡げていく責任があると考 えられる。

本研究は, 近畿バイオインダストリー振興会議主催, NPO 法人くらしとバイオ 21 共催の内閣府男女共同参画 局「Challenge Campaign ～女子高生 - 女子大生の理工 系分野への選択〜」の関連事業である「女子大生と考え る〜遺伝子組換え食品はなぜ嫌われる? 」 」ォーラム (平成 17 年 10 月) と日本食生活学会第 32 回大会（平成 18 年 5 月 13 日）での発表に解析を加えてまとめたものであ る。

\section{文献}

1）田部井豊：遺伝子組換え作物の現状，化学と生物，44（5), 345-349 (2006)

2）厚生労働省 : http://www.mhlw.go.jp/topics/idenshi/in dex.html

3）蔵田伸雄：遺伝子組換え技術に関する「科学の外側」の 問題，化学々生物，44（7），481-485（2006）

4）日野明寛：ぜひ知っておきたい遺伝子組換え農作物，幸 書房, 東京 (1999)

5） 日野明寬, 䅖山 浩, 栗原秀夫 : 遺伝子組換え農作物の 最新検査技術，日本食科工，50（3），103-114（2003）

6）松井博和：北海道に打ける遺伝子組換え作物栽培条例に みる合意形成，化学々生物，44（6），413-419（2006） 